\title{
Studies on Secretion of Gastric Intrinsic Factor in Man
}

\author{
S. ARDEMAN,* M.A., B.M. ; I. CHANARIN,† M.D., D.C.P.; J. C. DOYLE, $\ddagger$ M.B., B.S., F.R.C.S.
}

Brit. med. F., 1964, 2, 600-603

Until recently there has been no direct quantitative method for the measurement of intrinsic factor in gastric juice. Thus the presence of intrinsic factor has always been inferred indirectly by the ability of gastric juice to improve vitamin- $B_{12}$ absorption in patients with pernicious anaemia. This has prevented adequate investigations on the physiology of intrinsic factor production and on the effect of various pharmacological substances in stimulating its secretion. This subject has been reviewed by Glass (1963). Although various methods which attempt to assay intrinsic factor have been described, the most acceptable are those which take advantage of an antibody to human intrinsic factor to distinguish between this substance and other vitamin- $\mathrm{B}_{12}$-binding substances normally present in gastric juice (Abels, Bouma, and Nieweg, 1963 ; Jeffries, Sleisenger, and Benjamin, 1963 ; Ardeman and Chanarin, 1963).

The development of a simple and quantitative method for the assay of intrinsic factor has enabled us to study the secretion of intrinsic factor in normal subjects and hospital patients and to observe the effect of various stimulants in promoting its production. This paper reports our results.

\section{Materials and Methods}

Patients Studied.-(a) Seventeen tests were carried out on nine normal subjects, either medical students or members of the laboratory staff. (b) Twenty-two tests were made on 14 patients who were admitted with proved duodenal ulceration. (c) Twenty tests were carried out as part of the investigation of 19 patients. The diagnosis is given in Tables I and III. None had pernicious anaemia.

Gastric Fuice.-Disposable Ryle tubes were used for aspiration of the gastric contents with either continuous mechanical suction or frequent aspiration with a syringe. In all cases the fasting gastric contents were discarded and "resting" gastric juice was collected for the next 15 to 60 minutes. The following stimulants to gastric secretion were used: (a) histamine acid phosphate $0.04 \mathrm{mg} . / \mathrm{kg}$. body weight (Kay, 1953); this was preceded by 10 to $20 \mathrm{mg}$. of chlorpheniramine maleate; (b) Carbachol (0.25 mg.) subcutaneously ; (c) soluble insulin (20 units) intravenously. Gastric juice was collected for a further 60 to 120 minutes after injection of these substances. The gastric juice was centrifuged at 12,000 r.p.m. for 10 minutes and the clear fluid brought to $p \mathrm{H} 7$ to 7.5 with $40 \%$ $\mathrm{NaOH}$ where necessary. The gastric juice was assayed on the day of collection or within the next 24 hours. Samples of gastric juice were stored at $-20^{\circ} \mathrm{C}$.

Assay of Intrinsic Factor.-This was carried out by the method of Ardeman and Chanarin (1963). A working solution of ${ }^{60} \mathrm{Co}$-vitamin- $\mathrm{B}_{12}$ with specific activity of $0.025 \mu \mathrm{c}$./ $200 \mu \mathrm{mg}$. was used. One unit of intrinsic factor was designated as the amount that promoted the uptake of $1 \mu \mathrm{mg}$. of vitamin $\mathrm{B}_{12}$ to serum.

\footnotetext{
- Member of Scientific Staff, M.R.C. Experimental Haematology Research Unit, Department of Haematology, St. Mary's Hospital Medical School, London.

† Senior Lecturer, Department of Haematology, St. Mary's Hospital Medical School, London.

‡ Registrar, Surgical Unit, St. Mary’s Hospital Medical School, London.
}

Assay of peptic activity was carried out as described by Hunt (1948).

\section{Results}

\section{Intrinsic Factor Content of Resting Gastric Juice}

The results are shown in Tables I and II and Fig. 1.

Normal Subjects: The intrinsic-factor content of gastric juice collected for one hour without any stimulant to gastric secretion ranged from 900 to 8,300 units (mean 3,600).

Duodenal Ulcer Patients: The 60-minute intrinsic-factor secretion ranged from 600 to 3,200 units (mean 1,900 units).

Other Hospital Patients: The 60-minute intrinsic-factor secretion ranged from 500 to 5,900 units (mean 2,700 units).

Continuous Gastric Aspiration.-In two patients aspiration of the gastric secretion was continued over four hours and seven hours respectively. The hourly intrinsic-factor secretion in the first patient was 900,1,200, 3,400, and 4,400 units over the four consecutive hourly periods. The concentration varied from 43 to 79 units $/ \mathrm{ml}$. of gastric juice. In the second patient the intrinsic-factor secretion in the absence of any stimulus to gastric secretion was $1,000,900,900,2,100,900,1,300$, and

TABLE I

\begin{tabular}{|c|c|c|c|c|c|c|c|}
\hline \multirow{2}{*}{$\begin{array}{l}\text { Case } \\
\text { No. }\end{array}$} & \multirow[b]{2}{*}{ Age } & \multirow[b]{2}{*}{ Sex } & \multirow[b]{2}{*}{ Diagnosis } & \multicolumn{4}{|c|}{$\begin{array}{l}\text { Intrinsic Factor Secretion } \\
\text { in } 1 \mathrm{hr} \text {-Units* }\end{array}$} \\
\hline & & & & $\begin{array}{l}\text { Rest- } \\
\text { ing } \\
\text { Juice }\end{array}$ & $\left|\begin{array}{c}\text { Post- } \\
\text { Car- } \\
\text { bachol }\end{array}\right|$ & $\begin{array}{l}\text { Post- } \\
\text { Hist- } \\
\text { amine }\end{array}$ & $\begin{array}{l}\text { Post- } \\
\text { In- } \\
\text { sulin }\end{array}$ \\
\hline
\end{tabular}
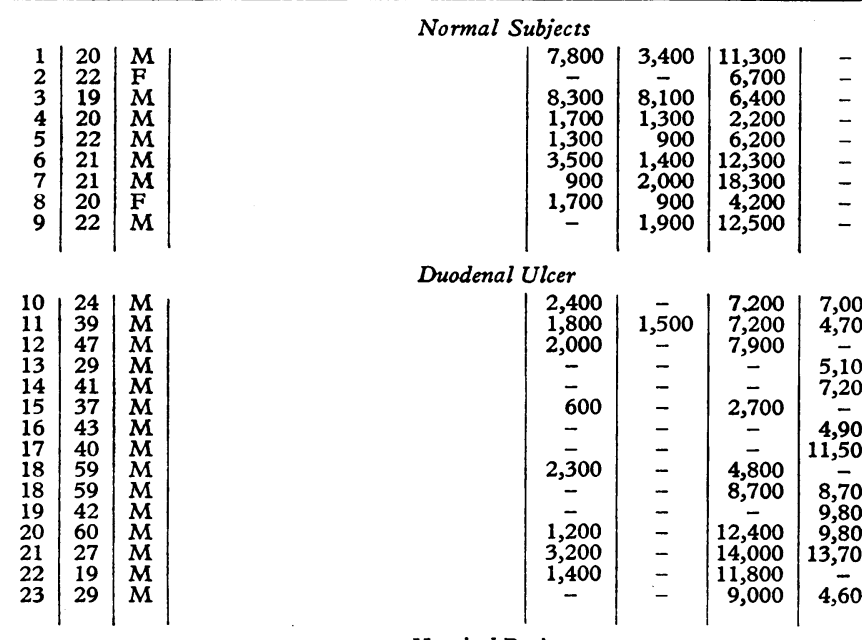

Duodenal Ulcer

* Results have been expressed to the nearest 100 units. 
TABLE II.-Gastric-intrinsic-factor Secretion in One Hour

\begin{tabular}{|c|c|c|c|c|c|c|c|c|c|}
\hline & & \multicolumn{2}{|c|}{ Resting Secretion } & \multicolumn{2}{|c|}{ Post-histamine } & \multicolumn{2}{|c|}{ Post-carbachol } & \multicolumn{2}{|c|}{ Post-insulin } \\
\hline & & Range & Mean & Range & Mean & Range & Mean & Range & Mean \\
\hline Normal subjects $\quad$. & .. & $\begin{array}{c}900-8,300 \\
(9-52)^{*}\end{array}$ & $\begin{array}{l}3,600 \\
(25)^{*}\end{array}$ & $\begin{array}{c}2,200-18,300 \\
(14-147)\end{array}$ & $\begin{array}{c}8,900 \\
(56)\end{array}$ & $\begin{array}{l}900-8,100 \\
(12-69)\end{array}$ & $\begin{array}{c}2,500 \\
(29)\end{array}$ & - & - \\
\hline Duodenal ulcer patients & .. & $\begin{array}{c}600-3,200 \\
(10-62)\end{array}$ & $\begin{array}{c}1,900 \\
(30)\end{array}$ & $\begin{array}{c}2,700-14,000 \\
(26-83)\end{array}$ & $\begin{array}{c}8,600 \\
(51)\end{array}$ & - & - & $\begin{array}{c}4,600-13,700 \\
(29-84)\end{array}$ & $\begin{array}{c}8,000 \\
(58)\end{array}$ \\
\hline Other hospital patients & $\ldots$ & $\begin{array}{l}500-5,900 \\
(20-124)\end{array}$ & $\begin{array}{c}2,700 \\
(56)\end{array}$ & $\begin{array}{c}1,000-8,600 \\
(14-111)\end{array}$ & $\begin{array}{c}4,200 \\
(53)\end{array}$ & - & - & - & - \\
\hline
\end{tabular}

* The figures in parentheses are the concentrations of intrinsic factor expressed as units per ml. gastric juice.

2,800 units an hour over a period of seven hours. The concentrations varied from 25 to 71 units $/ \mathrm{ml}$.

\section{Effects of Histamine on Secretion of Intrinsic Factor}

The injection of histamine was followed by an increase in gastric-intrinsic-factor secretion above the resting level (Tables I, II, and III ; Figs. 1 and 2).

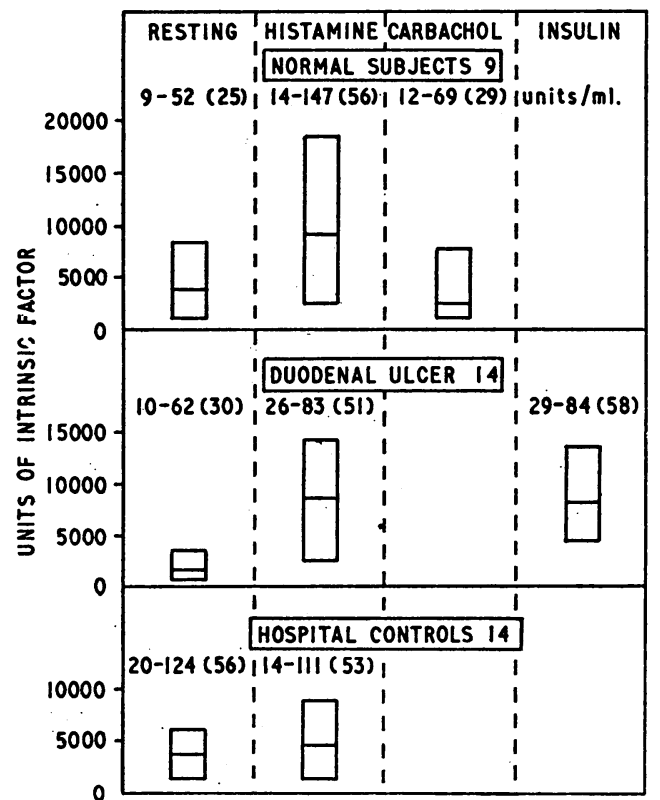

FIG. 1.-Secretion of gastric intrinsic factor over a period of 60 minutes in absence of any stimulant (resting), and following histamine, carbachol, and unsulin in various subjects. Concentration of intrinsic factor is also shown.

Normal Subjects : After histamine stimulation the intrinsicfactor secretion increased from a mean hourly resting level of 3,600 units to a mean of 8,900 units. The range varied from 2,200 to 18,300 units in one hour. Similarly the concentration of intrinsic factor increased from a mean of 25 units $/ \mathrm{ml}$. in the resting sample to a concentration of 56 units $/ \mathrm{ml}$. after histamine.

Duodenal Ulcer Patients: The increase in intrinsic-factor secretion was very similar to that found among normal subjects, the mean hourly secretion being 8,600 units and the mean concentration 51 units $/ \mathrm{ml}$.

Other Hospital Patients: The increase in intrinsic factor secretion was less than in the other groups, the range being from 1,000 to 8,600 units with a mean of 4,200 units.

Time of Intrinsic Factor and Hydrochloric Acid Production. -In 12 patients the gastric juice was collected in 15-minute aliquots, and both the intrinsic factor content and $\mathrm{HCl}$ content were noted. Three examples are shown in Fig. 2. In all cases the maximum secretion of intrinsic factor took place within 30 minutes of the injection of histamine, and in 9 of the 12 patients the peak secretion took place in the first 15 minutes.
After 30 minutes there was a marked fall in intrinsic-factor secretion, and at 45 minutes this had returned to the resting value. Fig. 2 also shows the relation of the secretion of intrinsic factor to that of hydrochloric acid. In 10 out of the 12 patients the maximum output of intrinsic factor was reached 15 to 30 minutes before the period of peak hydrochloric acid production.

Five patients had a histamine-fast achlorhydria after the augmented dose of histamine (Table III). All these patients had significant quantities of intrinsic-factor secretion, although in two the amount of intrinsic factor produced fell in the range found in patients with gastric atrophy (Ardeman and Chanarin, 1963). A gastric biopsy was performed on one of these patients (Case 41), and this showed atrophic gastritis.

\section{Effect of Insulin on Secre- tion of Intrinsic Factor}

These observations were made on patients with duodenal ulceration who were being investigated prior to gastric surgery or gastric freezing (Tables I and II ; Figs. 3 and 4).

The total secretion of intrinsic factor following the administration of 20 units of soluble insulin intravenously increased from a mean resting hourly value of 1,900 units to a mean hourly value of 8,000 units. The range was from 4,600 to 13,700 units. The concentration of intrinsic factor increased from a resting average value of 30 units $/ \mathrm{ml}$. to 58 units after insulin.

Relation Between Intrinsic Factor, Hydrochloric Acid, and Pepsin Production After Intravenous Insulin.-This was studied in 11 patients, and some of the results are shown in Figs. 3, 4, and 5. In seven patients the maximum intrinsicfactor secretion was reached 30 to 45 minutes after the injection of insulin, in three cases the peak was reached 45 to 60 minutes after the injection, and in one case it was reached after 60 to 75 minutes. The increased output of intrinsic factor lasted for only 15 to 30 minutes and was followed by a return to the resting level of secretion. As with histamine, intrinsic-factor secretion after insulin preceded the production of both hydrochloric acid and pepsin (Fig. 4) and usually coincided with the lowest blood-sugar level following the dose of insulin. Thus of 11 patients, hydrochloric acid and intrinsic-factor peaks coincided in two, in another two the hydrochloric acid peak was reached 15 minutes after that of intrinsic factor, in five 
the acid peak was reached 30 minutes later, and in the last two the acid peak was reached 45 minutes after that of intrinsic factor.

Peptic activity, measured in seven cases, closely followed the secretion of hydrochloric acid.

\section{Effect of Carbachol on Secretion of Intrinsic Factor}

Observations were made on eight normal subjects, on one patient with a duodenal ulcer, and on one patient with cirrhosis of the liver. This compound did not increase the secretion of intrinsic factor above the resting level (Tables I and II ; Figs. 1 and 5).

\section{Discussion}

Considerable amounts of intrinsic factor are present in the resting gastric secretion of subjects with a normal gastric mucosa. The basal secretion of intrinsic factor was about 2,500 units per hour over four hours in one patient and 1,400 units per hour over a seven-hour period in the second. This suggests a minimal daily intrinsic-factor output in these patients of 60,000 and 34,000 units respectively. Between 400 and 600 units of human intrinsic factor are required to produce maximum absorption of a $1-\mu \mathrm{g}$. dose of vitamin $\mathrm{B}_{12}$ using the urinary excretion method in patients with pernicious anaemia (unpublished observations, in press).

Both histamine and insulin produced a marked increase in the output of intrinsic factor above the resting level and both appeared to be equally effective stimulants to intrinsic-factor secretion. Sullivan, Herbert, and Castle (1963) showed that histamine produced a rise in the intrinsic-factor activity as assayed by the guinea-pig small-intestinal-mucosa homogenate method. The response was similar in the normal subjects and in the patients with duodenal ulcers. The rise was smaller among hospital controls presumably because these patients were of an older age-group and among them a high incidence of atrophic gastritis was probable.

The rise in intrinsic-factor production reached a maximum in the first 15 minutes after histamine and persisted for a total of 30 minutes at a high level, when there was a rapid decline to the resting level of secretion. The rise of intrinsic-factor output after insulin coincided with the maximal fall in blood sugar and thereafter, as with histamine, a high level persisted for 30 minutes before returning to the baseline levels.

Carbachol was shown by Baker and Mollin (1955) and by Mollin, Booth, and Baker (1957) to improve vitamin- $B_{12}$ absorption in some patients, and they suggested that it functioned by stimulating intrinsic-factor production. This does not seem to be the case, however, and the improved vitamin- $B_{12}$ absorption may be due to improved absorption by the small gut.

It appears that intrinsic factor, hydrochloric acid, and pepsin are produced independently and presumably by different cells of the gastric mucosa. Thus most of the acid is produced by the gastric mucosa after the peak intrinsic-factor secretion has declined. Further, considerable amounts of intrinsic factor may be secreted in the absence of any hydrochloric acid pro-

\begin{tabular}{|c|c|c|c|c|c|c|c|c|c|c|c|c|}
\hline \multirow{4}{*}{$\begin{array}{l}\text { Case } \\
\text { No. }\end{array}$} & \multirow{4}{*}{ Age } & \multirow{4}{*}{ Diagnosis } & \multicolumn{10}{|c|}{ Gastric Juice } \\
\hline & & & \multicolumn{5}{|c|}{ Resting Secretion $30 \mathrm{~min}$. } & \multicolumn{5}{|c|}{ Post-histamine $60 \mathrm{~min}}$. \\
\hline & & & \multirow{2}{*}{$\begin{array}{l}\text { Volume } \\
\mathrm{ml} .\end{array}$} & \multirow[b]{2}{*}{$p \mathrm{H}$} & \multirow[b]{2}{*}{$\mathrm{HCl}$} & \multicolumn{2}{|c|}{ Intrinsic Factor } & \multirow{2}{*}{$\begin{array}{l}\text { Volume } \\
\text { ml. }\end{array}$} & \multirow[b]{2}{*}{$p \mathrm{H}$} & \multirow[b]{2}{*}{$\mathrm{HCl}$} & \multicolumn{2}{|c|}{ Intrinsic Factor } \\
\hline & & & & & & Units $/ \mathrm{ml}$ & $\begin{array}{l}\text { Total } \\
\text { Units }\end{array}$ & & & & Units/ml. & $\begin{array}{l}\text { Total } \\
\text { units }\end{array}$ \\
\hline $\begin{array}{l}38 \\
39 \\
40 \\
41 \\
42\end{array}$ & $\begin{array}{l}57 \\
36 \\
60 \\
64 \\
52\end{array}$ & $\begin{array}{lll}\text { Hiatus hernia } & \ldots & \ldots \\
\text { Polycystic kidneys } & \ldots & \ldots \\
\text { Ulcerative colitis } & \ldots & \ldots \\
\text { Small-intestinal diverticulosis } \\
\text { Rheumatoid arthritis . }\end{array}$ & $\begin{array}{l}25 \\
30 \\
19 \\
- \\
-\end{array}$ & $\begin{array}{l}7 \cdot 6 \\
6 \cdot 6 \\
7 \cdot 8 \\
- \\
-\end{array}$ & $\begin{array}{l}\mathrm{Nil} \\
\mathrm{Nil} \\
\mathrm{Nil} \\
- \\
-\end{array}$ & $\begin{array}{r}25 \\
105 \\
9 \\
- \\
-\end{array}$ & $\begin{array}{r}600 \\
3,200 \\
200 \\
- \\
-\end{array}$ & $\begin{array}{l}30 \\
38 \\
47 \\
23 \\
50\end{array}$ & $\begin{array}{l}8 \cdot 0 \\
6 \cdot 8 \\
7 \cdot 5 \\
6 \cdot 9 \\
6 \cdot 5\end{array}$ & $\begin{array}{l}\text { Nil } \\
\text { Nil } \\
\text { Nil } \\
\text { Nil } \\
\text { Nil }\end{array}$ & $\begin{array}{r}55 \\
111 \\
21 \\
43 \\
87\end{array}$ & $\begin{array}{l}1,700 \\
4,200 \\
1,000 \\
1,000 \\
4,400\end{array}$ \\
\hline
\end{tabular}

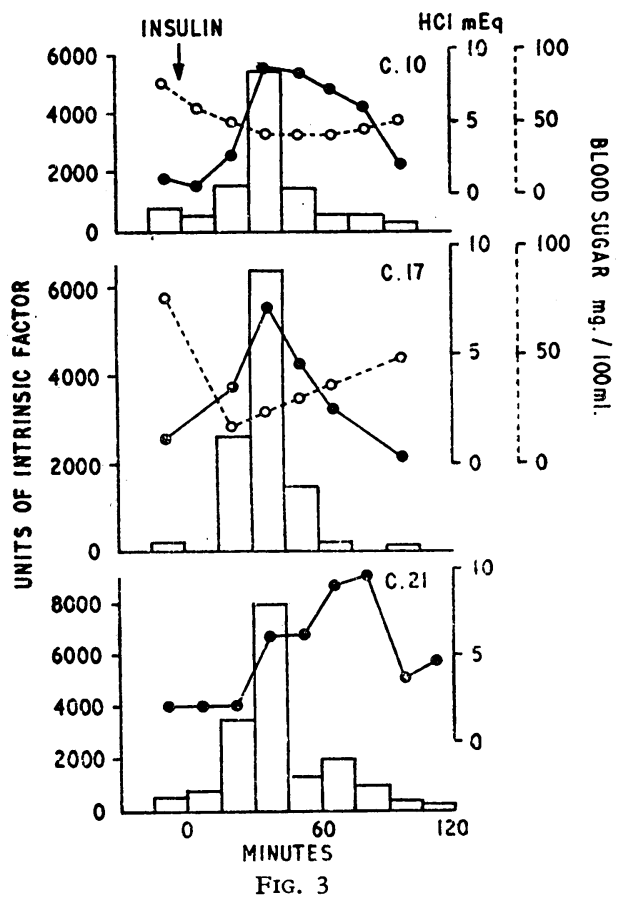

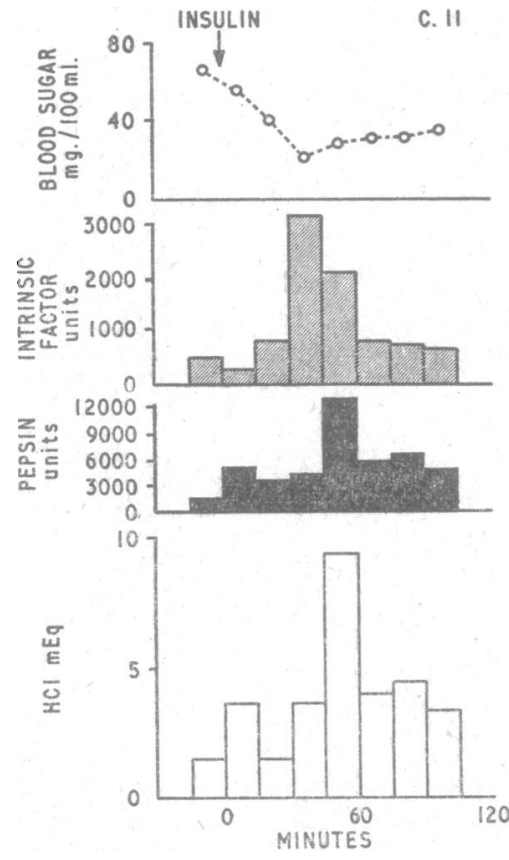

Fig. 4

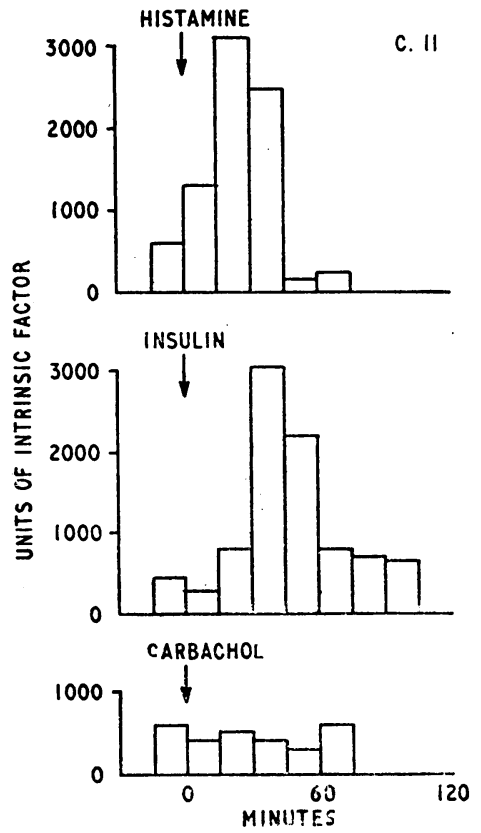

Fig. 5

FIG. 3.-Effect of insulin on secretion of intrinsic factor (columns) and on secretion of hydrochloric acid (solid dots) in three sub ects. The blood-sugar levels (open circles) are also shown. Fig. 4.-Effect of insulin on blood sugar, intrinsic-factor secretion, pepsin secretion, and hydrochloric acid secretion of Case 11. FIG. 5.-Effect of histamine, insulin, and carbachol on secretion of intrinsic factor by Case 11. 
duction. Finally, the secretion of intrinsic factor also precedes that of pepsin.

\section{Summary}

The secretion of gastric intrinsic factor was studied in normal subjects and in hospital patients. A considerable amount of intrinsic factor was present in gastric juice secreted in the absence of any stimulant, and this amount was normally far in excess of that required for the absorption of dietary vitamin $B_{12}$. Histamine and insulin were equally effective as stimulants of gastric-intrinsic-factor secretion, but carbachol did not produce an increase in secretion above the pre-injection level. The increased secretion of intrinsic factor following either histamine or insulin preceded the secretion of both acid and pepsin.

We wish to thank Professor W. T. Irvine both for his interest in the investigation and for permission to study his patients. We are indebted to Miss Valerie Berry for carrying out many of the intrinsicfactor assays and to $\mathrm{Mr}$. John Hall for the pepsin estimations.
ADDENDUM.-Since submitting this paper for publication, Jeffries, Benjamin, and Sleisenger (Clin. Res., 1964, 12, 209) have reported the effect of various pharmacological substances on the secretion of intrinsic factor. Their results using histamine are similar to those reported above.

\section{REFERENCES}

Abels, J., Bouma, W., and Nieweg, H. O. (1963). Biochim. biophys. Acta (Amst.), 71, 227.

Ardeman, S., and Chanarin, I. (1963). Lancet, 2, 1350.

Baker, S. J., and Mollin, D. L. (1955). Rev. Hémat., 10, 180.

Glass, G. B. J. (1963). Physiol. Rev., 43, 529.

Hunt, J. N. (1948). Biochem. f., 42, 104.

Jeffries, G. H., Sleisenger, M. H., and Benjamin, L. L. (1963). F. clin. Invest., 42, 442.

Kay, A. W. (1953). Brit. med. f., 2, 77.

Mollin, D. L., Booth, C. C., and Baker, S. J. (1957). Brit. F. Haemat., 3, 412 .

Sullivan, L. W., Herbert, V., and Castle, W. B. (1963). F. clin. Invest., 42, 1443.

\title{
Antibacterial Activity of Lincomycin and Pristinamycin : A Comparison with Erythromycin
}

\author{
MARY BARBER,* M.D. ; PAMELA M. WATERWORTH,*† F.I.M.L.T.
}

Brit. med. F., 1964, 2, 603-606

Lincomycin is an antibiotic isolated from a strain of Streptomyces lincolnensis in the Research Laboratories of the Upjohn Company, Michigan, in 1961 (Mason, Dietz, and Deboer, 1962). It is a monobasic compound and is obtained as the hydrochloride, in which form it is very readily soluble in water. The hydrochloride has the empirical formula $\mathrm{C}_{18} \mathrm{H}_{34} \mathrm{~N}_{2} \mathrm{O}_{6} \mathrm{~S}$. $\mathrm{HCl} \cdot \frac{1}{2} \mathrm{H}_{2} \mathrm{O}$ (molecular weight 452) (Herr and Bergy, 1962). Early reports indicate that it has an activity similar to that of erythromycin against Gram-positive cocci both in vitro and in experimental infections in mice (Lewis, Clapp, and Grady, 1962), although the high solubility and low molecular weight suggest that it is not a macrolide.

Pristinamycin (pyostacine) was isolated in the RhonePoulenc Research Laboratories in the nineteen-fifties from a strain of Streptomyces pristinae spiralis. A series of laboratory and clinical studies were published together in Semaine Thérapeutique (Benazet et al., 1962). It is a mixture of two antibiotics, and recent studies have shown that there is a broad chemical similarity between pristinamycin and a number of other antibiotic mixtures-namely, staphylomycin (de Somer and van Dijck, 1955 ; van Dijck, Vanderhaeghe, and de Somer, 1957), ostreogrycin (E 129, Glaxo) (see Garrod and Waterworth, 1956), streptogramin (Merck \& Co.) (Verwey, West, and Miller, 1958), synergistin (PA 144, Pfizer \& Co.) (Celmer, 1955-6 ; Hobbs and Celmer, 1959), and mikamycin (Arai, Fukahara, Nakamura, Yonehara, and Umezawa, 1958; Yamaguchi, 1961). Partial cross-resistance with erythromycin has been recorded in the case of ostreogrycin (Garrod and Waterworth, 1956) and streptogramin (Jones, Nichols, and Finland, 1956).

\section{Materials and Methods}

Lincomycin hydrochloride and pristinamycin were kindly supplied respectively by Upjohn Ltd. and May \& Baker Ltd.
Solutions of lincomycin were prepared in distilled water. Pristinamycin, however, is of very low solubility in water, and stock solutions ( $1 \mathrm{mg} . / \mathrm{ml}$.) were therefore prepared in alcohol. Bacteriostatic tests were carried out by preparing serial doubling dilutions of antibiotic in nutrient agar and inoculating with a standard 1-mm. loopful of an overnight broth culture, except where otherwise stated diluted 1 in 500 . Laked or heated blood was added for those bacteria requiring it.

\section{Bacteriostatic Activity}

The general spectrum of bacteriostatic activity of lincomycin and pristinamycin is shown in Table I. It will be seen that both compounds are highly active against Staph. aureus, Str. pyogenes, and Str. pneumoniae. Strains of Str. faecalis and $H$. influenzae were fairly highly sensitive to pristinamycin, but strains of both species were inhibited only by from 4-16 $\mu \mathrm{g}$. of lincomycin $/ \mathrm{ml}$. The strains of Neisseria tested were all highly sensitive to pristinamycin but resistant to lincomycin. All strains of Shigella, Salmonella, and Escherichia spp. were highly resistant to both antibiotics.

The 120 staphylococci referred to in Table I were a random selection of strains recently isolated in the routine hospital laboratory. The numbers resistant to various antibiotics were: penicillin 72 , streptomycin 40 , tetracycline 41 , erythromycin 17 , methicillin 3, and chloramphenicol 1. Further tests were carried out with a collection of 12 erythromycin-resistant strains of Staph. aureus which were typical representatives of one or other of the two resistant types described by Garrod (1957). The results are given in Table II. Seven of the strains showed double resistance to erythromycin and spiramycin, and three of these seven were also resistant to lincomycin. The remaining

* Department of Bacteriology, Postgraduate Medical School of London. +Working with a full-time grant from the Medical Research Council. 